\title{
23. LOW-MOLECULAR-WEIGHT HYDROCARBONS IN SEDIMENTS OF SITES 752, 754, 755 (BROKEN RIDGE), 757 AND 758 (NINETYEAST RIDGE), CENTRAL INDIAN OCEAN ${ }^{1}$
}

\author{
R. G. Schaefer, ${ }^{2}$ R. Littke, ${ }^{2}$ and D. Leythaeuser ${ }^{2}$
}

\begin{abstract}
Core samples taken during Leg 121 drilling aboard the JOIDES Resolution in the central Indian Ocean were analyzed for their low-molecular-weight hydrocarbon contents. Forty-three samples from the Broken Ridge and 39 samples from the Ninetyeast Ridge drill sites, deep-frozen on board immediately after recovery, were studied by a dynamic headspace technique (hydrogen-stripping/thermovaporization). Light hydrocarbons (saturated and olefinic) with two to four carbon atoms, and toluene as a selected aromatic compound, were identified. Total $\mathrm{C}_{2}-\mathrm{C}_{4}$ saturated hydrocarbon yields vary considerably from virtually zero in a Paleogene calcareous ooze from Hole 757B to nearly 600 nanogram/gram of dry-weight sediment (parts per billion) in a Cretaceous claystone from Hole 758A. An increase of light-hydrocarbon yields with depth, and hence with sediment temperature, was observed from Hole 758A samples down to a depth of about 500 meters below seafloor. Despite extreme data scatter due to lithological changes over this depth interval, this increased yield indicates the onset of temperature-controlled hydrocarbon formation reactions.

Toluene contents are also extremely variable (generally between 10 and $100 \mathrm{ppb}$ ) and reach more than $300 \mathrm{ppb}$ in two samples of tuffaceous lithology (Sections 121-755A-17R-4 and 121-758A-48R-4). As for the saturated hydrocarbons, there was also an increase of toluene yields with increasing depth in Hole 758A.
\end{abstract}

\section{INTRODUCTION}

During the cruise of the JOIDES Resolution in the central Indian Ocean (in May and June 1988) a total of 82 sediment samples were collected for this study from five drill sites on Leg 121 of the Ocean Drilling Program (ODP). These samples were collected on board with special precautions taken immediately upon recovery from the core barrel. Precautions included collection of samples only from the ends of the $1.5-\mathrm{m}$ sections cut from the core liner. By these means, the contamination of the samples by acetone, which is usually applied in large quantities during core-cutting procedures aboard ship, was minimized. This contamination problem has been discussed in detail in our previous studies of Deep Sea Drilling Project (DSDP) samples (cf., Schaefer et al., 1983b; Schaefer and Leythaeuser, 1985, 1987). All samples for the present study were stored in sealed vials and deep-frozen on board for analysis in our laboratory. This study focuses on organic geochemical aspects and examines the conditions for the generation of low-molecular-weight hydrocarbons as determined in 43 core samples from the Broken Ridge and 39 samples from the Ninetyeast Ridge drill sites of Leg 121 (Fig. 1).

Light hydrocarbons are widespread constituents in most deepsea sediments (Hunt, 1975, 1984; Whelan and Hunt, 1981, 1982; Jasper et al., 1984; Whelan, 1984; Whelan et al., 1984). A main reason for studying the occurrence and distribution of these compounds is that they represent sensitive indicators of the onset of thermal hydrocarbon generation and are indicative of redistribution processes in the pore spaces of sedimentary rocks (e.g., by diffusion). Previous analyses of low-molecular-weight hydrocarbons in sediments of DSDP Legs 71, 75, 79, 89, and 93 (Schaefer et al., 1983a, 1983b, 1984; Schaefer and Leythaeuser, 1984, 1985, 1987) were designed to address such objectives. The same applies to the present study, although it was clear from data collected on board (low organic carbon contents, low maturity, etc.) that light

\footnotetext{
'Weissel, J., Peirce, J., Taylor, E., Alt, J., et al., 1991. Proc. ODP, Sci. Results, 121: College Station, TX (Ocean Drilling Program).

${ }^{2}$ Forschungszentrum Jülich $\mathrm{GmbH}$, Institut für Erdöl und Organische Geochemie, Postfach 1913, D-5170 Jülich, Federal Republic of Germany.
}

hydrocarbons would be only trace constituents at these Indian Ocean sites. Our initial results also led to the decision that this study be limited to hydrocarbons with two to four carbon atoms (saturated and unsaturated compounds) and to toluene, as an example of a low-molecular-weight aromatic hydrocarbon. Regardless of this limitation, the data presented are believed to be not only of documentary value in the framework of deep-sea drilling research, but reconfirm and extend previous observations concerning geochemical behavior of light hydrocarbons in diagenetically young sediments.

\section{METHODS}

\section{Samples}

Eighty-two sediment samples (approximately 5-10 g) were collected from the cores immediately after they had been cut into sections on deck. Samples were stored in 20 -mL screw-capped glass flasks, sealed with aluminum foil, and placed in a deep freezer. The samples remained in a deep-frozen condition (approximately $-20^{\circ} \mathrm{C}$ ) until the analyses were performed in the laboratory at KFA Jülich.

\section{Determination of Organic Carbon Contents and Light-Hydrocarbon Yields}

Organic carbon contents were measured on the "thermovaporized" sediment samples (see below) after treatment with hot $6 \mathrm{~N}$ $\mathrm{HCl}$ by a combustion method (LECO Carbon Analyzer IR 112). The accuracy of this method is still rather high at organic carbon levels of $0.1 \mathrm{wt} \%$ (dry weight) or even less (10\% relative standard deviation, or coefficient of variation).

The low-molecular-weight hydrocarbons (total molecular range $C_{2}$ to $C_{7}$ ) were analyzed by a slightly modified dynamic headspace technique ("hydrogen stripping/thermovaporization") combined with capillary gas chromatography described in detail in our previous studies of DSDP Legs 71, 75, 79, 89, and 93 sediments (Schaefer et al., 1983a, 1983b, 1984; Schaefer and Leythaeuser, 1984, 1985, 1987).

The analytical method used comprises both the mobilization of the hydrocarbons from the sediment samples and subsequent capillary gas chromatography in a single-step procedure carried 

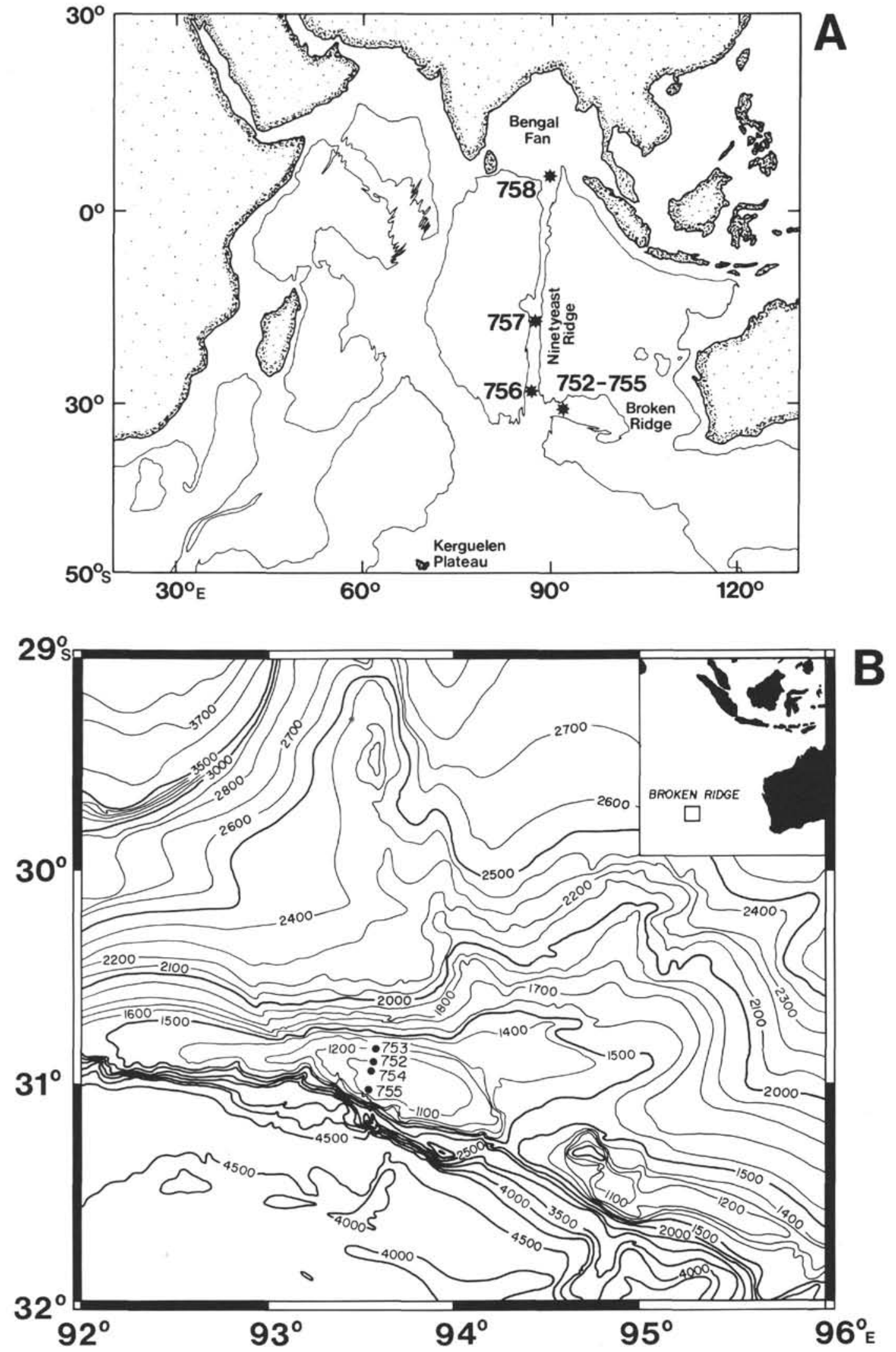

Figure 1. A. General location map showing ODP drill sites of the study area. B. Map showing Broken Ridge sites in more detail. Bathymetry in meters. 
out in a closed gas-flow system. Briefly, a small portion of the frozen sediment sample (generally less than $1 \mathrm{~g}$ ) is placed in the flow system of the gas chromatograph, the hydrogen carrier gas serving as the stripping gas. The rock sample is heated to $150^{\circ} \mathrm{C}$ for $10 \mathrm{~min}$ in a gas flow of $10 \mathrm{~mL} / \mathrm{min}$. Prior to the gas chromatographic separation, the thermovaporized (or "thermodesorbed") compounds are passed through a filter-section of dry $\mathrm{CaCl}_{2}$ in order to prevent the pore water from entering the gas chromatographic column.

In contrast to our previous studies, we decided to restrict this analysis to the gaseous compounds except methane (i.e., ethane, ethene, propane, propene, isobutane, isobutene and butene- 1 (chromatographically not resolved), $n$-butane, trans-butene-2, and cis-butene-2), and toluene. This selection of compounds resulted mainly from the fact that most other hydrocarbons (including benzene, for instance) could not be determined with sufficient accuracy because of peaks overlapping with, and limited separation of, unknown compounds in the molecular weight range of interest. In addition to the gaseous compounds, only toluene concentrations could be determined. Owing to analytical limitations, the method does not include the measurement of methane because of inefficiency of the cold trap involved. Hydrocarbon yields (Tables 1-3) were obtained by external standardization of the flame-ionization detector signal with $n$-butane and represent, therefore, $n$-butane weight equivalents. Different response factors for the various compounds were not considered owing to the lack of reliable data. We can assume that this simplification is acceptable for the kind of data presented here.

As discussed later, we have indications that the yields obtained by our thermovaporization method represent the total quantities of saturated and aromatic light hydrocarbons both dissolved in the pore water and adsorbed at, or distributed in, the mineral/kerogen matrix. In contrast, part of the olefinic compounds might be generated by low-temperature "hydrous pyrolysis" under the conditions applied. In addition, the "artificial" formation of olefins by the drilling process cannot completely be ruled out (Faber et al., 1988). This possibility could not apply, however, to samples obtained by hydraulic piston coring.

Concentration values obtained by our method should not be compared with corresponding data obtained by other methods, e.g., static headspace analysis of DSDP Leg 22 sediments (Hunt, 1974), unless partition coefficients are known.

\section{Relative Standard Deviation of Hydrocarbon Yield Measurements}

The relative standard deviation (or coefficient of variation) of hydrocarbon stripping yields was determined to be about $10 \%-$ $20 \%$ for rock samples containing relatively low to moderate light hydrocarbon stripping yields of $40-3000 \mathrm{ng} / \mathrm{g}$ dry-weight sediment (Schaefer et al., 1978). There are reasons to believe, however, that the pronounced scatter of the low thermovaporization yields in the present study is not an instrumental problem, but is mainly caused by heterogeneities in the rock samples (see also following discussion about the influence of the thermovaporization temperature on hydrocarbon yield).

As a result of the anticipated low light-hydrocarbon concentrations in the sediment samples, the standard deviation of the concentration values was determined for a selected sample. The measurements of 10 aliquots of Sample 121-757B-20X-5, 147 $150 \mathrm{~cm}$, resulted in the following relative standard deviations: ethane $( \pm 51 \%)$, propane $(54 \%)$, isobutane $(91 \%), n$-butane $(53 \%)$, and toluene $(69 \%)$. The standard deviations for the olefinic hydrocarbons were even higher (exceeding even $100 \%$ for propene, trans-, and cis-butene-2) and, therefore, the olefin concentrations in Table 3 should be considered with much more caution.

They will not be discussed in detail and are included in this table only for documentary purposes. Although these results are only valid for the particular sample studied, we believe that such fluctuations are at least typical for the reliability of the individual measurements discussed below. The organic carbon determination for the aliquots of this particular sample gave a standard deviation of $\pm 29 \%$. There was no clear relationship between organic carbon contents and light-hydrocarbon yields.

\section{Influence of Thermovaporization Temperature on Hydrocarbon Yield}

In order to investigate the influence of the thermovaporization temperature as an important analytical parameter for the determination of the hydrocarbon yield, we selected a sediment sample for a systematic study. To this end, aliquots of Sample 121-757B$17 \mathrm{H}-6,0-1 \mathrm{~cm}$, a nannofossil calcareous ooze from $156.60 \mathrm{~m}$ below seafloor (mbsf), were introduced in the sampling tube and heated to temperatures between ambient $\left(22^{\circ} \mathrm{C}\right)$ and $150^{\circ} \mathrm{C}$. The analytical results show that, despite considerable data scatter, there is a significant increase with temperature for all compounds, with the highest yields, in general, at $150^{\circ} \mathrm{C}$ (Table 1). The low yields at $22^{\circ} \mathrm{C}$ mainly represent those hydrocarbons dissolved in the pore water, whereas at higher temperatures additional amounts of the same compounds are mobilized from more strongly adsorbing sites or from closed pores in the sediment matrix. In this particular example, the increase for the saturated hydrocarbons and toluene is nearly 10 -fold; the olefinic compounds increase by a factor of 11-15. The corresponding change in the hydrocarbon composition is exemplified in Figure 2, where the relevant sections of the gas chromatograms between ethene and cis-butene- 2 are depicted for the measurements at $22^{\circ}, 80^{\circ}$, and $150^{\circ} \mathrm{C}$, respectively. At this stage of our investigation it is very difficult to determine whether part of the olefinic compounds are formed by possible chemical reactions during thermovaporization at the higher temperatures (e.g., $150^{\circ} \mathrm{C}$ ) from the immature organic matter. However, in view of the occurrence of olefins at $22^{\circ} \mathrm{C}$ and similar concentration ratios in relation to their saturated homologs

Table 1. Thermovaporization hydrocarbon yield as a function of temperature of Sample 121-757B-17H-6, 0-1 cm.

\begin{tabular}{|c|c|c|c|c|c|c|c|c|c|c|c|}
\hline $\begin{array}{l}\mathrm{C}_{\text {org }} \\
(\%)\end{array}$ & $\begin{array}{c}\text { "Thermodesorption" } \\
\text { temperature } \\
\left({ }^{\circ} \mathrm{C}\right)\end{array}$ & $\stackrel{2}{\text { Ethane }}$ & $\begin{array}{c}3 \\
\text { Propane }\end{array}$ & $\stackrel{4}{\text { Methylpropane }}$ & $\begin{array}{c}5 \\
n \text {-Butane }\end{array}$ & Toluene & $\begin{array}{c}7 \\
\text { Ethene }\end{array}$ & $\begin{array}{c}8 \\
\text { Propene }\end{array}$ & $\stackrel{9}{9}$ & $\begin{array}{c}10 \\
\text { trans-Butene-2 }\end{array}$ & $\begin{array}{c}11 \\
\text { cis-Butene-2 }\end{array}$ \\
\hline 0.06 & 22 & 2.19 & 2.78 & 0.68 & 1.31 & 2.00 & 0.50 & 0.87 & 1.45 & 0.23 & 0.16 \\
\hline 0.06 & 40 & 1.66 & 3.78 & 1.87 & 2.45 & 2.70 & 0.23 & 0.83 & 2.26 & 0.31 & 0.35 \\
\hline 0.07 & 60 & 3.96 & 5.56 & 1.74 & 2.71 & 3.04 & 0.83 & 2.11 & 3.43 & 0.48 & 0.36 \\
\hline 0.07 & 80 & 4.34 & 6.34 & 1.57 & 3.40 & 2.52 & 1.19 & 2.02 & 3.26 & 0.67 & 0.51 \\
\hline 0.07 & 100 & 18.83 & 18.73 & 3.81 & 8.73 & 4.94 & 1.77 & 2.48 & 2.20 & 0.61 & 0.55 \\
\hline 0.12 & 110 & 6.56 & 10.12 & 2.92 & 5.12 & 8.97 & 4.89 & 4.55 & 7.63 & 1.21 & 1.11 \\
\hline 0.05 & 120 & 30.67 & 19.61 & 5.09 & 13.19 & 10.57 & 4.64 & 4.86 & 14.18 & 1.63 & 1.12 \\
\hline 0.14 & 130 & 4.67 & 7.50 & 2.33 & 4.20 & 6.59 & 2.70 & 3.70 & 8.73 & 1.29 & 1.19 \\
\hline 0.11 & 150 & 22.27 & 25.96 & 7.48 & 15.29 & 15.41 & 7.00 & 11.47 & 15.67 & 2.81 & 2.40 \\
\hline
\end{tabular}

Note: Hydrocarbon yield expressed in nanograms per gram of dry-weight sediment. Numbers 2-5 and 7-11 refer to peak numbering in Figure 2. 
Table 2. Organic carbon contents in percent of dry-weight sediment from selected core samples.

\begin{tabular}{|c|c|c|c|c|}
\hline $\begin{array}{l}\text { Core, section, } \\
\text { interval }(\mathrm{cm})\end{array}$ & Age & Lithology & $\begin{array}{l}\text { Depth } \\
\text { (mbsf) }\end{array}$ & $\begin{array}{l}\mathrm{C}_{\text {org }} \\
(\%)\end{array}$ \\
\hline \multicolumn{5}{|l|}{$121-752 \mathrm{~A}-$} \\
\hline $19 X-3,149-150$ & Paleogene & Nannofossil calcareous chalk & 175.59 & 0.07 \\
\hline $19 X-4,0-1$ & Paleogene & Nannofossil calcareous chalk & 175.60 & 0.13 \\
\hline $29 X-5,149-150$ & Paleogene & Nannofossil calcareous chalk & 275.19 & 0.13 \\
\hline \multicolumn{5}{|l|}{$121-752 \mathrm{~B}-$} \\
\hline $6 \mathrm{R}-4,0-1$ & Paleogene & Calcareous chalk & 311.10 & 0.05 \\
\hline $7 R-3,147-150$ & Paleogene & Calcareous chalk & 320.57 & 0.06 \\
\hline $8 \mathrm{R}-6,0-1$ & Paleogene & Calcareous chalk & 331.90 & 0.08 \\
\hline $9 \mathrm{R}-1,0-1$ & Paleogene & Calcareous chalk & 335.40 & 0.08 \\
\hline 10R-5, 149-150 & Paleogene & Calcareous chalk & 352.59 & 0.07 \\
\hline $11 R-2,0-1$ & Paleogene & Volcanic ash with micrite & 356.30 & 0.13 \\
\hline $12 R-2,149-150$ & Cretaceous & Calcareous chalk & 367.39 & 0.07 \\
\hline $14 \mathrm{R}-2,149-150$ & Cretaceous & Calcareous chalk & 386.59 & 0.13 \\
\hline $17 \mathrm{R}-4,147-150$ & Cretaceous & Calcareous chalk & 418.57 & 0.07 \\
\hline $19 \mathrm{R}-2,149-150$ & Cretaceous & Calcareous chalk & 434.59 & 0.13 \\
\hline \multicolumn{5}{|l|}{$121-754 \mathrm{~A}-$} \\
\hline IH-4, 0-1 & Neogene & Foraminifer nannofossil ooze & 4.50 & 0.13 \\
\hline $7 \mathrm{H}-6,0-1$ & Neogene & Foraminifer nannofossil ooze & 61.60 & 0.13 \\
\hline $11 \mathrm{H}-6,0-1$ & Neogene & Nannofossil ooze & 100.40 & 0.04 \\
\hline $12 \mathrm{H}-6,0-1$ & Paleogene & Nannofossil ooze & 110.10 & 0.07 \\
\hline $13 X-3,0-1$ & Paleogene & Nannofossil ooze & 115.30 & 0.13 \\
\hline $14 X-4,0-1$ & Cretaceous & Nannofossil ooze & 126.50 & 0.13 \\
\hline $20 \mathrm{~N}-1,149-150$ & Cretaceous & Calcareous chalk & 164.09 & 0.08 \\
\hline $21 \mathrm{~N}-1,0-1$ & Cretaceous & Calcareous chalk & 167.10 & 0.09 \\
\hline \multicolumn{5}{|l|}{$121-754 \mathrm{~B}-$} \\
\hline $7 \mathrm{R}-2,149-150$ & Cretaceous & Calcareous chalk & 173.99 & 0.11 \\
\hline $8 \mathrm{R}-1,0-1$ & Cretaceous & Calcareous chalk & 180.60 & 0.08 \\
\hline $9 \mathrm{R}-4,0-1$ & Cretaceous & Limestone & 194.80 & 0.08 \\
\hline $10 \mathrm{R}-4,149-150$ & Cretaceous & Limestone & 205.99 & 0.08 \\
\hline $11 \mathrm{R}-2,149-150$ & Cretaceous & Limestone & 212.59 & 0.08 \\
\hline $12 \mathrm{R}-2,0-1$ & Cretaceous & Limestone & 220.70 & 0.13 \\
\hline $13 R-6,149-150$ & Cretaceous & Limestone & 236.85 & 0.10 \\
\hline $14 \mathrm{R}-7,0-1$ & Cretaceous & Limestone & 247.40 & 0.13 \\
\hline $15 \mathrm{R}-5,0-1$ & Cretaceous & Limestone & 254.20 & 0.06 \\
\hline $16 \mathrm{R}-2,149-150$ & Cretaceous & Limestone & 260.89 & 0.08 \\
\hline $17 \mathrm{R}-2,0-1$ & Cretaceous & Limestone & 269.10 & 0.13 \\
\hline $24 \mathrm{R}-2,39-40$ & Cretaceous & Limestone and chert & 337.19 & 0.17 \\
\hline $25 \mathrm{R}-1,0-1$ & Cretaceous & Limestone and chert & 345.00 & 0.23 \\
\hline \multicolumn{5}{|l|}{$121-755 \mathrm{~A}-$} \\
\hline $1 \mathrm{R}-4,149-150$ & Neogene & Foraminifer nannofossil ooze & 5.98 & 0.13 \\
\hline $6 \mathrm{R}-2,149-150$ & Cretaceous & Ashy limestone & 75.09 & 0.13 \\
\hline $9 \mathrm{R}-1,149-150$ & Cretaceous & Tuff with micrite & 102.69 & 0.13 \\
\hline $11 \mathrm{R}-1,67-68$ & Cretaceous & Tuff with micrite & 121.17 & 0.18 \\
\hline $12 \mathrm{R}-1,0-1$ & Cretaceous & Tuff with micrite & 131.10 & 0.26 \\
\hline $13 R-4,51-52$ & Cretaceous & Porcellanite & 145.61 & 0.13 \\
\hline $15 R-4,0-1$ & Cretaceous & Tuff with micrite & 164.38 & 0.13 \\
\hline $17 \mathrm{R}-4,38-39$ & Cretaceous & Tuff with glauconite & 184.05 & 0.13 \\
\hline $19 \mathrm{R}-5,149-150$ & Cretaceous & Tuff & 206.19 & 0.13 \\
\hline
\end{tabular}

over the large temperature range, it is assumed that the yield data shown in this study represent mainly thermally desorbed hydrocarbons.

\section{RESULTS AND DISCUSSION}

\section{Sites 752, 754, and 755}

\section{Regional Setting}

Broken Ridge is a rifted fragment of an oceanic platform (the Kerguelen-Heard Plateau) now situated at $30^{\circ} \mathrm{S}$ in the central Indian Ocean. Sites 752 to 755 form a north-south transect along the crest of Broken Ridge (for details see Fig. 1). The transect was designed to sample the entire dipping truncated sequence at Broken Ridge (Peirce, Weissel, et al., 1989).

\section{Light-Hydrocarbon Yields at Broken Ridge}

The low-molecular-weight hydrocarbon yields and the organic carbon contents of the samples are summarized in Tables 2 and 3. Organic carbon contents are close to $0.1 \%$ in all samples $(0.04 \%-$ $0.13 \%$ range), except for a few samples with slightly higher values at the bottom of Hole 754B in Cores 121-754B-24R and -25R $(0.17 \%$ and $0.23 \%)$ and in Cores $121-755 \mathrm{~A}-11 \mathrm{R}$ and $-12 \mathrm{R}$ of Hole $755 \mathrm{~A}(0.18 \%$ and $0.26 \%)$. For a detailed discussion of organic carbon contents at these sites see Littke et al. (this volume).

The variation of light-hydrocarbon yields is extreme. For example, the sum of $\mathrm{C}_{2}-\mathrm{C}_{4}$ saturated hydrocarbons (sum of ethane, propane, isobutane, and $n$-butane) reaches nearly $400 \mathrm{ng} / \mathrm{g}$ of dry-weight sediment (ppb) in a nannofossil ooze of Paleogene age (Section 121-754A-12H-6) and is nearly two orders of magnitude 
Table 2 (continued).

\begin{tabular}{|c|c|c|c|c|}
\hline $\begin{array}{l}\text { Core, section, } \\
\text { interval }(\mathrm{cm})\end{array}$ & Age & Lithology & $\begin{array}{l}\text { Depth } \\
\text { (mbsf) }\end{array}$ & $\begin{array}{l}C_{\text {org }} \\
(\%)\end{array}$ \\
\hline \multicolumn{5}{|l|}{ 121-757B- } \\
\hline $14 \mathrm{H}-6,0-1$ & Paleogene & Nannofossil calcareous ooze & 127.60 & 0.08 \\
\hline $17 \mathrm{H}-6,0-1$ & Paleogene & Nannofossil calcareous ooze & 156.60 & 0.11 \\
\hline $18 \mathrm{H}-6,0-1$ & Paleogene & Nannofossil calcareous ooze & 166.30 & 0.08 \\
\hline $19 \mathrm{H}-4,0-3$ & Paleogene & Nannofossil calcareous ooze & 173.00 & 0.13 \\
\hline $20 \times-5,147-150$ & Paleogene & Nannofossil calcareous ooze & 182.17 & 0.05 \\
\hline $21 \times-6,0-3$ & Paleogene & Calcareous ooze & 190.20 & 0.13 \\
\hline $22 \times-4,0-3$ & Paleogene & Calcareous ooze & 196.90 & 0.08 \\
\hline $23 X-4,0-3$ & Paleogene & Calcareous ooze & 206.50 & 0.07 \\
\hline $26 X-2,0-3$ & Paleogene & Lapilli tuff & 232.50 & 0.13 \\
\hline $31 X-1,0-1$ & Paleogene & Tuff & 279.40 & 0.08 \\
\hline $35 \mathrm{X}-3,0-3$ & Paleogene & Tuff & 320.90 & 0.08 \\
\hline \multicolumn{5}{|l|}{$121-758 \mathrm{~A}-$} \\
\hline $1 \mathrm{H}-4,0-3$ & Neogene & Nannofossil ooze with clay & 4.50 & 0.13 \\
\hline $2 \mathrm{H}-5,0-1$ & Neogene & Nannofossil ooze with clay & 12.00 & 0.13 \\
\hline $3 \mathrm{H}-6,144-145$ & Neogene & Nannofossil ooze with clay & 24.54 & 0.13 \\
\hline $4 \mathrm{H}-6,0-1$ & Neogene & Nannofossil ooze with clay & 32.70 & 0.13 \\
\hline $6 \mathrm{H}-5,147-150$ & Neogene & Nannofossil ooze with clay & 51.87 & 0.13 \\
\hline $11 \mathrm{H}-5,0-1$ & Neogene & Nannofossil ooze & 98.80 & 0.13 \\
\hline $14 X-3,0-1$ & Neogene & Nannofossil chalk & 124.70 & 0.14 \\
\hline $22 X-3,0-1$ & Paleogene & Nannofossil chalk & 202.00 & 0.13 \\
\hline $26 \times-5,0-3$ & Paleogene & Calcareous nannofossil chalk & 243.70 & 0.11 \\
\hline $29 \times-3,0-1$ & Paleogene & Calcareous nannofossil ooze and chalk & 269.59 & 0.13 \\
\hline $31 X-5,0-1$ & Cretaceous & Calcareous nannofossil chalk & 291.90 & 0.04 \\
\hline $33 \times-3,0-1$ & Cretaceous & Calcareous nannofossil chalk & 308.30 & 0.13 \\
\hline $35 \times-2,0-1$ & Cretaceous & Foraminiferal calcareous chalk & 326.10 & 0.09 \\
\hline $39 X-1,149-150$ & Cretaceous & Calcareous chalk & 359.09 & 0.18 \\
\hline $41 X-5,0-1$ & Cretaceous & Clay with foraminifers, nannofossils, and ash & 383.01 & 0.13 \\
\hline $42 \times-2,0-1$ & Cretaceous & Clay with foraminifers and nannofossils & 388.10 & 0.13 \\
\hline $44 X-C C, 0-5$ & Cretaceous & Porcellanite & 399.60 & 0.13 \\
\hline $45 \mathrm{X}-\mathrm{CC}, 0-2$ & Cretaceous & Porcellanite & 405.60 & 0.13 \\
\hline $48 R-4,147-148$ & Cretaceous & Tuff & 437.17 & 0.13 \\
\hline $49 \mathrm{R}-1,49-50$ & Cretaceous & Tuff & 441.39 & 0.13 \\
\hline $50 \mathrm{R}-2,0-1$ & Cretaceous & Tuff & 452.10 & 0.13 \\
\hline $51 R-1,0-1$ & Cretaceous & Tuff & 460.20 & 0.13 \\
\hline $52 \mathrm{R}-1,0-1$ & Cretaceous & Tuff & 469.90 & 0.13 \\
\hline $52 \mathrm{R}-1,145-150$ & Cretaceous & Tuff & 471.35 & 0.90 \\
\hline $54 \mathrm{R}-1,145-150$ & Cretaceous & Calcareous tuff & 490.65 & 0.08 \\
\hline $55 \mathrm{R}-4,141-142$ & Cretaceous & Basalt & 504.59 & 0.09 \\
\hline $56 \mathrm{R}-2,0-1$ & Cretaceous & Clayey tuff & 509.90 & 0.13 \\
\hline $57 \mathrm{R}-1,139-140$ & Cretaceous & Clayey tuff & 519.29 & 0.13 \\
\hline
\end{tabular}

lower in the Cretaceous limestone of the same site (Section 121-754B-9R-4).

Light-hydrocarbon yields appear to vary with geological age. The Neogene samples of Site 754 (three samples) and Site 755 (one sample) have rather low saturated hydrocarbon yields (about $50-100 \mathrm{ppb}$ ). The toluene content ranges from 8 to nearly $50 \mathrm{ppb}$. A comparison of these values with corresponding data of DSDP Site 586 (Ontong-Java Plateau), where a section of Neogene nannofossil ooze was analyzed by the same technique (Schaefer and Leythaeuser, 1985), shows that the saturated hydrocarbon yield at Sites 754 and 755 is higher by a factor of 3 to 5 , whereas the toluene content is similar.

The samples of Paleogene age of Site 752 and 754 reveal a strong variation in light-hydrocarbon yields. Most yields, however, are higher than in the Neogene sediments. Saturated hydrocarbon yields reach nearly $400 \mathrm{ppb}$ (Sample 121-754A-12H-6, $0-1 \mathrm{~cm}$ ) as a result of enhanced ethane and propane contents, and are between 100 and nearly $300 \mathrm{ppb}$ in most other samples of this age. The toluene contents are generally also higher than in the Neogene. Values exceeding $100 \mathrm{ppb}$ were found in samples from 175.79 and $331.90 \mathrm{mbsf}$ at Site 752 . A possible explanation for the difference in yields between the Neogene and Paleogene samples could be an elevated primary production and/or more favorable conditions for preservation of organic matter in the
Paleogene. In addition, the volcanic ash content is lower in the Paleogene section relative to the Neogene section.

The Cretaceous rocks at Sites 752 and 754 (mainly calcareous chalks and limestones with varying ash contents) have low saturated hydrocarbon yields (in general, between 10 and $100 \mathrm{ppb}$ ) and toluene contents between 7 and about $70 \mathrm{ppb}$. Particularly low yields are observed at about 195 mbsf and between 220 and 248 mbsf at Site 754. This low yield may be a result of the elevated volcanic ash contents at these depths.

The saturated hydrocarbon yields of the Cretaceous sediments of Site 755 are of a similar range as those from the other two sites. Very low yields, however, were found in samples from 121.17 and $131.10 \mathrm{mbsf}$ (as at $194.80 \mathrm{mbsf}$ of Site 754 ). The most striking result in this sediment section is the very high toluene content $(315 \mathrm{ppb})$ in a tuff sample obtained from $184.05 \mathrm{mbsf}$. In addition, high toluene contents appear to be generally correlated with high olefin yields. We are not certain at this stage of our investigation whether this correlation of high toluene and olefin yield is due to mere coincidence or reflects a chemical relationship. Moreover, in view of the low organic-carbon content of Sample 121-755A$17 \mathrm{R}-4,38-39 \mathrm{~cm}$, with $0.13 \% \mathrm{C}_{\text {org }}$ and the very low maturity level of the organic matter, the origin of such high toluene contents cannot be explained as a generation feature. In a previous study we interpreted high relative toluene concentrations to be caused 
Table 3. Low-molecular-weight hydrocarbon yield in nanograms per gram of dry-weight sediment from selected core samples.

\begin{tabular}{|c|c|c|c|c|c|c|c|c|c|c|}
\hline $\begin{array}{l}\text { Core, section, } \\
\text { interval }(\mathrm{cm})\end{array}$ & Ethane & Propane & Methylpropane & n-Butane & Toluene & Ethene & Propene & Isobutene + Butene-1 & trans-Butene-2 & cis-Butene-2 \\
\hline \multicolumn{11}{|l|}{$121-752 \mathrm{~A}-$} \\
\hline $19 X-3,149-150$ & 112.6 & 62.9 & 35.5 & 55.3 & 106.4 & 47.2 & 58.7 & 222.4 & 27.5 & - \\
\hline $19 X-4,0-1$ & 36.2 & 26.5 & 7.9 & 19.8 & 16.4 & 12.0 & 7.2 & 16.4 & 2.3 & 1.9 \\
\hline $29 \times-5,149-150$ & 33.6 & 26.9 & 7.6 & 10.9 & 7.4 & 2.3 & 0.7 & 3.4 & 0.8 & 0.8 \\
\hline \multicolumn{11}{|l|}{$121-752 \mathrm{~B}-$} \\
\hline $6 \mathrm{R}-4,0-1$ & 47.1 & 51.3 & 14.9 & 31.4 & 28.3 & 13.1 & 17.4 & 45.1 & 10.8 & - \\
\hline $7 \mathrm{R}-3,147-150$ & 61.5 & 72.2 & 21.2 & 40.4 & 36.3 & 14.8 & 28.8 & 58.0 & 13.0 & - \\
\hline $8 R-6,0-1$ & 36.7 & 58.8 & 16.8 & 23.8 & 120.2 & 40.0 & 108.4 & 440.5 & 107.9 & 78.4 \\
\hline $9 \mathrm{R}-1,0-1$ & 13.6 & 62.1 & 7.5 & 8.4 & 73.9 & 17.4 & 0.9 & 179.2 & 43.1 & 29.1 \\
\hline $10 \mathrm{R}-5,149-150$ & 52.5 & 53.2 & 14.2 & 30.9 & 45.4 & 21.4 & 42.6 & 136.4 & 77.9 & - \\
\hline $11 \mathrm{R}-2,0-1$ & 25.3 & 26.4 & 6.8 & 16.8 & 7.8 & 4.3 & 7.3 & 5.7 & 1.4 & 1.3 \\
\hline $12 \mathrm{R}-2,149-150$ & 38.9 & 43.9 & 9.1 & 21.3 & 14.8 & 3.1 & 4.3 & 4.6 & 1.1 & 1.0 \\
\hline $14 \mathrm{R}-2,149-150$ & 11.0 & 8.9 & 2.9 & 6.5 & 7.2 & 3.6 & 3.8 & 5.1 & 0.9 & 0.7 \\
\hline $17 \mathrm{R}-4,147-150$ & 14.8 & 17.1 & 4.6 & 10.3 & 8.6 & 5.9 & 8.5 & 13.9 & 1.9 & 1.7 \\
\hline $19 R-2,149-150$ & 5.3 & 7.7 & 1.8 & 3.9 & 4.9 & 1.8 & 1.9 & 3.8 & 0.7 & 0.6 \\
\hline \multicolumn{11}{|l|}{$121-754 \mathrm{~A}-$} \\
\hline $1 \mathrm{H}-4,0-1$ & 20.6 & 21.5 & 6.3 & 12.6 & 14.2 & 10.3 & 14.0 & 19.1 & 3.0 & 2.2 \\
\hline $7 \mathrm{H}-6,0-1$ & 49.7 & 28.6 & 9.5 & 14.8 & 8.3 & 9.7 & 8.6 & 10.8 & 1.7 & 1.7 \\
\hline $11 \mathrm{H}-6,0-1$ & 16.9 & 21.0 & 6.4 & 9.6 & 9.2 & 6.3 & 16.7 & 38.2 & 4.6 & 5.8 \\
\hline $12 \mathrm{H}-6,0-1$ & 133.9 & 139.6 & 35.3 & 70.6 & 48.1 & 15.5 & 27.6 & 30.3 & 5.6 & 5.3 \\
\hline $13 \times-3,0-1$ & 29.2 & 18.3 & 7.1 & 14.6 & 10.7 & 10.1 & 7.3 & 13.6 & 1.9 & 1.7 \\
\hline $14 \times-4,0-1$ & 6.8 & 6.5 & 2.7 & 5.8 & 10.1 & 3.7 & 3.8 & 5.7 & 1.3 & 1.2 \\
\hline $20 \mathrm{~N}-1,149-150$ & 31.6 & 9.2 & 5.1 & 11.7 & 21.1 & 6.6 & 5.4 & 13.5 & 1.7 & 1.4 \\
\hline $21 \mathrm{~N}-1,0-1$ & 14.6 & 20.6 & 7.3 & 15.6 & 18.8 & 4.8 & 11.3 & 38.6 & 11.5 & 12.1 \\
\hline \multicolumn{11}{|l|}{$121-754 \mathrm{~B}-$} \\
\hline $7 \mathrm{R}-2,149-150$ & 45.1 & 58.0 & 16.3 & 30.2 & 68.7 & 25.5 & 53.1 & 103.7 & 15.0 & - \\
\hline $8 \mathrm{R}-1,0-1$ & 25.8 & 34.0 & 9.4 & 17.9 & 19.3 & 5.2 & 6.9 & 12.3 & 2.3 & 1.8 \\
\hline $9 R-4,0-1$ & 1.4 & 1.8 & 0.6 & 1.1 & 9.8 & 0.9 & 0.9 & 6.8 & 0.4 & 0.3 \\
\hline $10 \mathrm{R}-4,149-150$ & 25.5 & 32.0 & 7.6 & 16.4 & 18.0 & 14.9 & 12.2 & 65.3 & 16.9 & - \\
\hline $11 R-2,149-150$ & 17.2 & 15.6 & 7.5 & 11.7 & 41.4 & 0.4 & 20.6 & 76.7 & 10.8 & - \\
\hline $12 \mathrm{R}-2,0-1$ & 8.0 & 11.7 & 3.4 & 5.8 & 8.7 & 4.1 & 5.0 & 9.9 & 1.1 & 1.0 \\
\hline $13 R-6,149-150$ & 1.4 & 5.0 & 1.7 & 2.9 & 8.8 & 0.4 & 2.2 & 15.2 & 0.5 & 0.3 \\
\hline $14 \mathrm{R}-7,0-1$ & 3.3 & 3.3 & 1.2 & 2.6 & 5.5 & 1.5 & 1.5 & 5.0 & 0.8 & 0.6 \\
\hline $15 \mathrm{R}-5,0-1$ & 11.3 & 38.4 & 13.2 & 24.5 & 28.0 & 0.9 & 21.9 & 41.2 & 8.7 & - \\
\hline $16 \mathrm{R}-2,149-150$ & 12.4 & 19.1 & 6.7 & 11.2 & 26.5 & 11.2 & 20.4 & 48.1 & 11.9 & - \\
\hline $17 \mathrm{R}-2,0-1$ & 16.4 & 25.7 & 7.8 & 12.7 & 34.0 & 10.6 & 16.2 & 69.4 & - & - \\
\hline $24 \mathrm{R}-2,39-40$ & 14.5 & 16.8 & 4.3 & 8.9 & 15.5 & 2.5 & 3.4 & 5.0 & 0.8 & 0.7 \\
\hline $25 \mathrm{R}-1,0-1$ & 12.8 & 14.0 & 3.4 & 9.2 & 13.9 & 3.4 & 5.2 & 5.0 & 1.1 & 0.8 \\
\hline \multicolumn{11}{|l|}{$121-755 \mathrm{~A}=$} \\
\hline $1 R-4,149-150$ & 35.6 & 27.1 & 10.6 & 21.5 & 48.1 & 13.8 & 14.3 & 21.6 & 5.7 & 6.2 \\
\hline $6 \mathrm{R}-2,149-150$ & 10.9 & 9.1 & 3.5 & 6.9 & 37.6 & 4.4 & 5.5 & 9.5 & 1.3 & 1.0 \\
\hline $9 \mathrm{R}-1,149-150$ & 14.4 & 5.6 & 3.8 & 7.5 & 55.7 & 4.3 & 2.1 & 11.2 & 1.4 & 1.1 \\
\hline $11 \mathrm{R}-1,67-68$ & 1.9 & 2.2 & 0.8 & 1.4 & 13.8 & 0.7 & 0.5 & 1.5 & 0.2 & 0.1 \\
\hline $12 \mathrm{R}-1,0-1$ & 1.9 & 2.5 & 0.8 & 1.6 & 4.3 & 0.6 & 0.6 & 1.2 & 0.3 & 0.1 \\
\hline $13 R-4,51-52$ & 20.9 & 22.4 & 7.9 & 12.6 & 55.9 & 8.5 & 17.2 & 98.6 & 14.4 & 10.1 \\
\hline $15 \mathrm{R}-4,0-1$ & 18.1 & 22.8 & 6.6 & 12.5 & 40.1 & 6.1 & 6.8 & 18.8 & 1.9 & 1.4 \\
\hline $17 \mathrm{R}-4,38-39$ & 10.6 & 36.0 & 16.0 & 8.5 & 315.6 & 20.4 & 1.1 & 269.4 & 79.9 & 53.3 \\
\hline $19 \mathrm{R}-5,149-150$ & 10.9 & 17.8 & 6.3 & 10.4 & 74.6 & 2.5 & 4.5 & 11.2 & 1.3 & 1.1 \\
\hline
\end{tabular}

by the preferential removal of polar compounds from moving compaction waters by adsorption on the mineral surfaces or in the kerogen matrix (Schaefer et al., 1983a, 1983b). This hypothesis, however, needs further clarification and experimental support.

\section{Sites 757 and 758}

\section{Regional Setting}

Ninetyeast Ridge is interpreted as the 80 - to 40 -Ma-old volcanic trace of a hotspot now located below the Kerguelen Plateau (Peirce, Weissel, et al., 1989). The ridge extends over $4500 \mathrm{~km}$ in a north-south direction and is covered by pelagic, carbonate-rich sediments thickening northward. Site 757 is located in the central part of the ridge at $17^{\circ} \mathrm{S}$, and Site 758 is at the northern end of Ninetyeast Ridge, where recent sedimentation is influenced by terrestrial debris from the Bengal Fan.

\section{Light-Hydrocarbon Yields at Ninetyeast Ridge}

The low-molecular-weight hydrocarbon yields and the organic carbon contents of the samples are summarized in Tables 2 and 3. Organic carbon contents are close to $0.1 \%(0.04 \%-0.18 \%$ range) except for one tuff sample (121-758A-52R-1, 145-150 cm) of 471.35 mbsf depth with $0.9 \% \mathrm{C}_{\text {org }}$.

The Paleogene section of Site 757 is characterized by lowmolecular-weight hydrocarbon yields (sum of ethane, propane, isobutane, and $n$-butane) of $40-200 \mathrm{ppb}$ (with one exception of virtually zero in Sample 121-757B-14H-6, 0-1 cm). The yields are, except for samples below $232 \mathrm{mbsf}$, significantly lower than those of the Paleogene section from Sites 752, 754, and 758. Similarly, toluene content is generally lower in the Ninetyeast Ridge sediments, although these concentrations are variable, ranging from 8 to about $140 \mathrm{ppb}$. The lapilli tuff (Sample 121- 
Table 3 (continued).

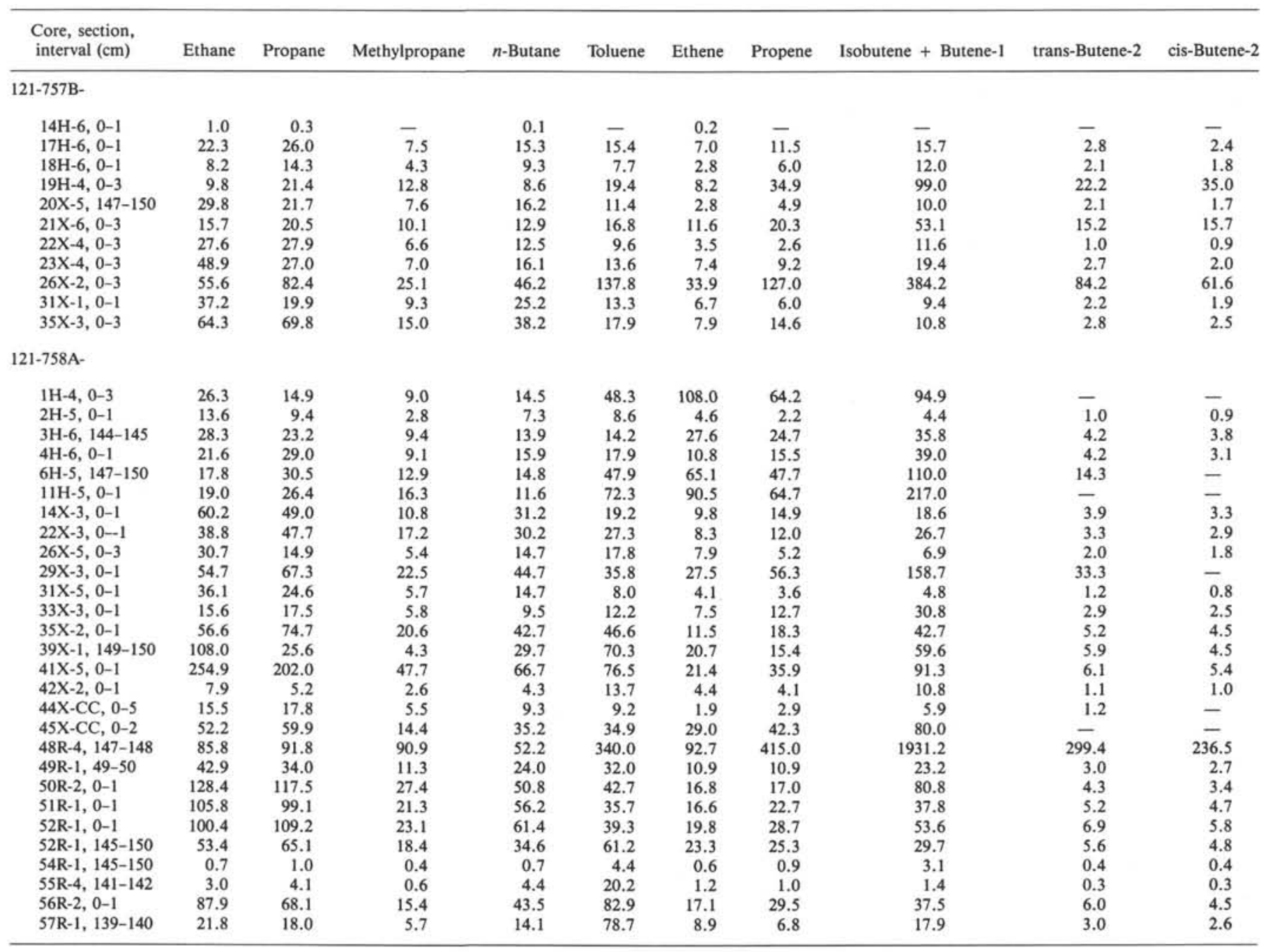

Note: Dash $=$ not determined (value below or near detection limit, or uncertain because of peak overlapping).

757B-26X-2, 0-3 cm) from 232.5 mbsf is certainly an exception to the low toluene contents. A similar reason as that for Sample 121-755A-17R-4, 38-39 cm, may explain its high toluene concentration. The lower light-hydrocarbon yields of the samples from the interval between 127 to 207 mbsf can be explained by the fact that these sediments consist of pure carbonates $(96 \%$ carbonate content). They were deposited in a similar setting as the Neogene carbonates of the Broken Ridge area (Sites 754 and 755) and reveal similar hydrocarbon yields. The tuff sample from 232.5 mbsf mentioned above reflects the lithologic change from mainly carbonate to a tuffaceous section. In the upper part of the latter section, elevated porosities were measured $(50 \%-60 \%$ vs. about $40 \%$ in the carbonate section).

Drilling at Site 758 penetrated a section of Neogene, Paleogene, and Cretaceous sediments. As indicated in Table 3, lighthydrocarbon yields have a tendency to increase with depth although the data scatter is significant (Figs. 3 and 4). The highest value of about $570 \mathrm{ppb}$ for the sum of saturated hydrocarbons occurs at 383.01 mbsf in the Cretaceous. As at Site 755 , the highest toluene content at Site 758 is also encountered in a sample of tuffaceous lithology (121-758A-48R-4, 147-148 cm) from 437.17 mbsf. As mentioned previously, a toluene content of 340 ppb is remarkably high in light of the low hydrocarbon potential of these sediments. The toluene is not, most probably, of autochthonous origin in this particular sample.

The saturated hydrocarbon yields from Site 758 sediments remain rather high down to $470 \mathrm{mbsf}$, but are drastically reduced at 490.65 and $504.59 \mathrm{mbsf}$. This reduction roughly correlates with the occurrence of a basalt layer around these depths. The lighthydrocarbon yields, including toluene, in the Cretaceous sediments at Ninetyeast Ridge are considerably higher than in the sediments of corresponding age at Broken Ridge. This difference may be due to the fact that the sediments at Site 758 , in contrast to the Broken Ridge sites, were not uplifted, and the hydrocarbons were retained as far as possible. The lower yields in the Cretaceous sections of Sites 752 and 754 could be due, therefore, to pressure release during uplift processes. The rather high yields in Hole $758 \mathrm{~A}$ at 383.01 and $437.17 \mathrm{mbsf}$ correlate with high-porosity intervals near these depths. Below $490 \mathrm{mbsf}$ the porosities are strongly reduced with an exception at $510 \mathrm{mbsf}$, where a saturated hydrocarbon yield of $215 \mathrm{ppb}$ was measured.

\section{CONCLUSIONS}

Trace amounts of low-molecular-weight hydrocarbons occurred in all samples investigated in this study. Quantities of individual $\mathrm{C}_{2}$ to $\mathrm{C}_{4}$ hydrocarbons (saturated and olefinic), as well 
R. G. SCHAEFER, R. LITTKE, D. LEYTHAEUSER
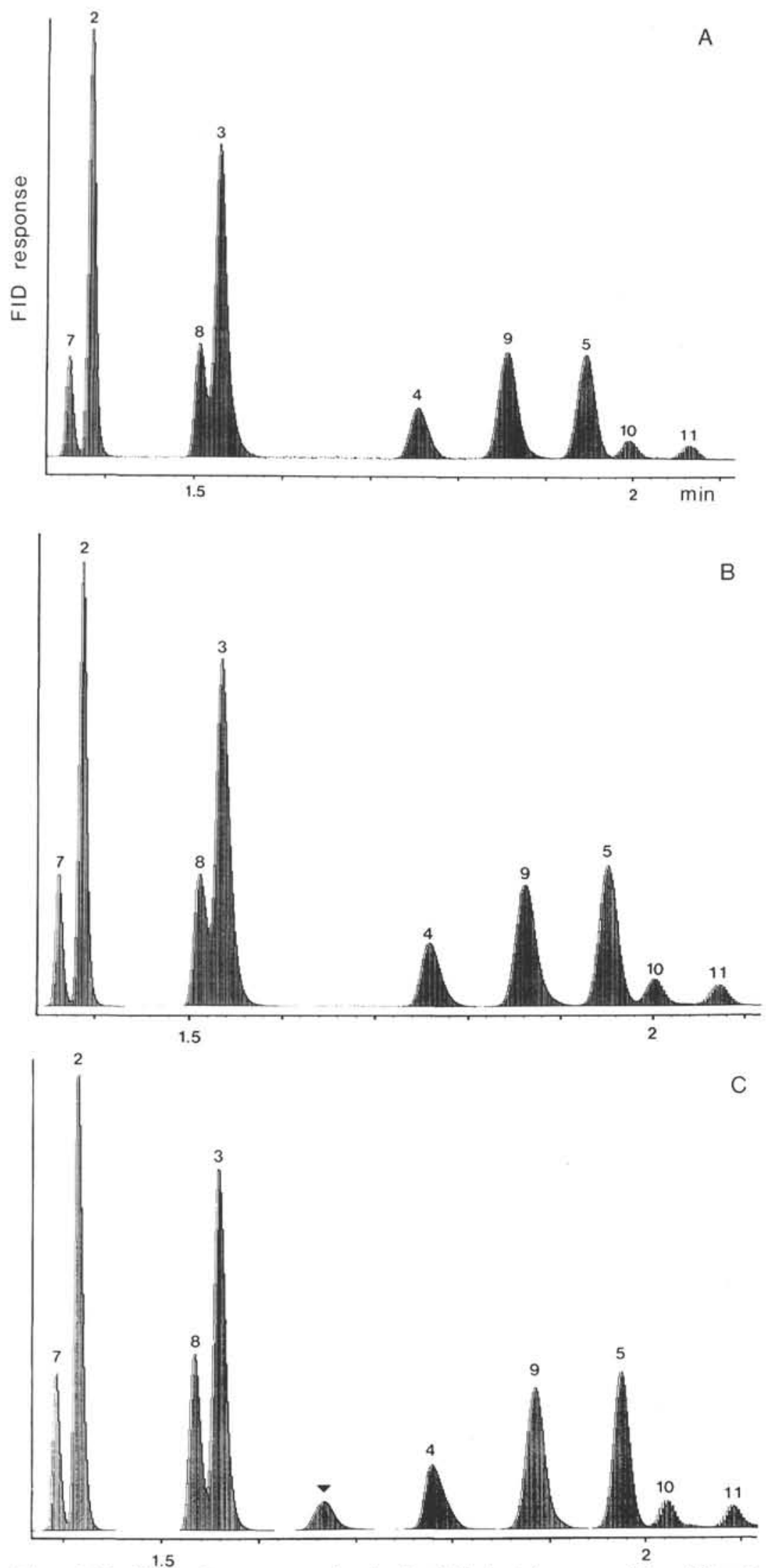

Figure 2. Partial gas chromatograms showing $\mathrm{C}_{2}-\mathrm{C}_{4}$ hydrocarbon composition of Sample $121-757 \mathrm{~B}-17 \mathrm{H}-6,0-1 \mathrm{~cm}$, as a function of thermovaporization temperature. For peak identification see Table 1 . The compound marked by a triangle is an unknown compound. A. $22^{\circ} \mathrm{C}$. B. $80^{\circ} \mathrm{C} . \mathrm{C} .150^{\circ} \mathrm{C}$, 


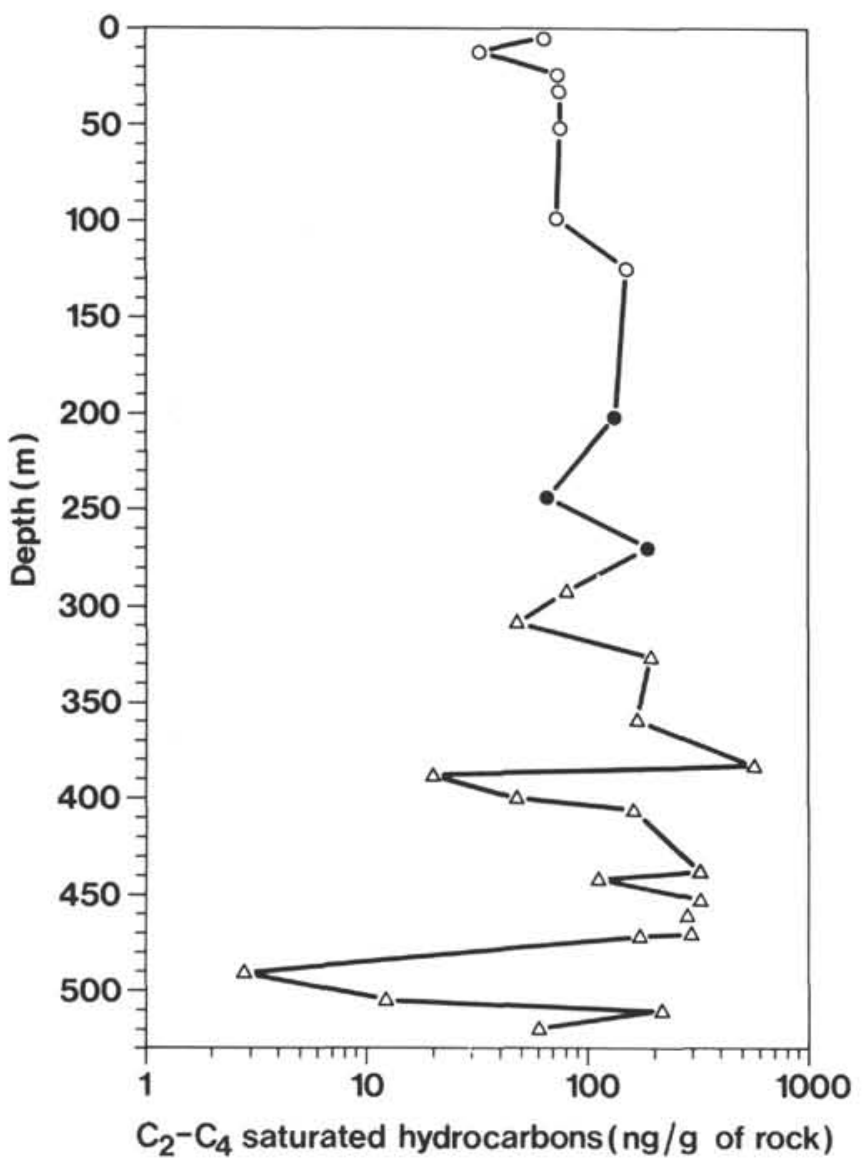

Figure 3. Sum of $\mathrm{C}_{2}-\mathrm{C}_{4}$ saturated hydrocarbon yield (ng/g of dry-weight sediment) plotted against depth for core samples of Hole 758A. Open circles $=$ Neogene, solid circles $=$ Paleogene, and triangles $=$ Cretaceous .

as toluene as a selected aromatic compound, varied considerably in the sample series. Part of this data scatter was due to inhomogeneities in the rock samples, as exemplified by analysis of a selected sample of Core 121-757B-20X. Relative standard deviations (coefficients of variation) of about $50 \%$ were measured in this sample for ethane, propane, and $n$-butane.

Apart from these fluctuations, other systematic differences appeared to be associated with changes in geological age and/or lithology of the sediments. For example, hydrocarbon yields in the Paleogene sediments of Broken Ridge (Sites 752 and 754) were generally higher than in the Neogene section (Sites 754 and 755 ). This difference may be due to a reduced primary production of organic matter and higher volcanic ash contents in the latter. Like the Neogene, the Cretaceous calcareous chalks and limestones from Broken Ridge also revealed lower hydrocarbon yields. In contrast to Broken Ridge, most of the Paleogene section at Ninetyeast Ridge (Site 757) revealed considerably lower yields, which may be explained by the similar lithologic composition (i.e., by the occurrence of practically pure carbonates) as of the Neogene at Broken Ridge.

Despite considerable data scatter, a depth-related increase of hydrocarbon yields was found in Hole 758A sediments where total $\mathrm{C}_{2}-\mathrm{C}_{4}$ saturated hydrocarbon yields increased from about 50 $\mathrm{ppb}$ to more than $300 \mathrm{ppb}$ (maximum of $570 \mathrm{ppb}$ reached at 383 mbsf). The light-hydrocarbon yields, including toluene, in the Cretaceous sediments at Ninetyeast Ridge are considerably higher than in corresponding sediments from Broken Ridge. This difference was tentatively interpreted to be a result of the lack of uplift

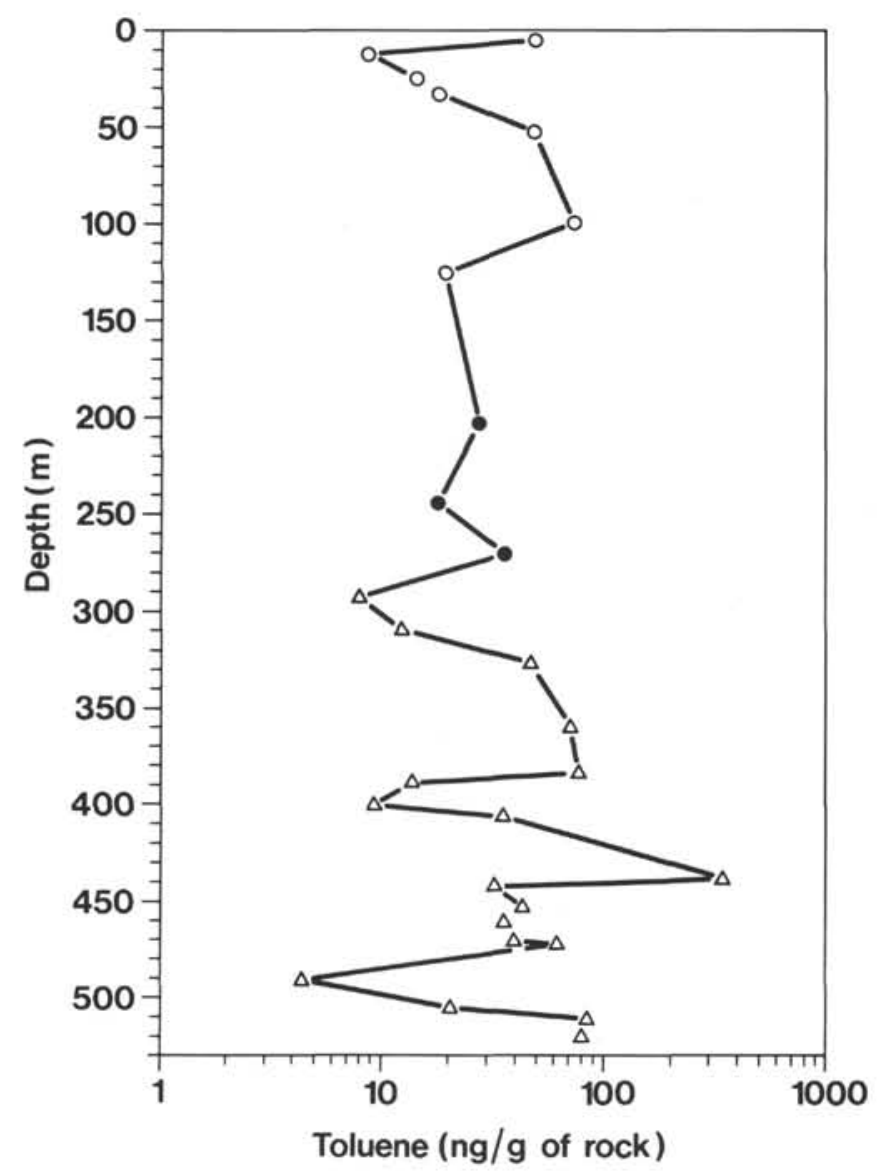

Figure 4. Toluene yield (ng/g of dry-weight sediment) plotted against depth for core samples of Hole 758A. Open circles $=$ Neogene, solid circles $=$ Paleogene, and triangles $=$ Cretaceous .

at Site 758 . The hydrocarbons in these sediments, therefore, were retained in the pore network more efficiently than in the same section at Broken Ridge. Accordingly, the lower yields at Sites 752,754 , and 755 could be due to pressure release during uplift processes associated with rifting.

The highest toluene yields were observed in two tuff samples of Cretaceous age (Sections 121-755A-17R-4 and 121-758A$48 \mathrm{R}-4$ ) with 315 and $340 \mathrm{ppb}$, respectively. In view of the fact that tuffs do not contain indigenous organic matter and the low maturity of these sediments, such high toluene contents cannot be explained as a generation feature. In a previous study of DSDP Leg 71 (Schaefer et al., 1983a, 1983b) we interpreted high toluene contents in relation to its saturated homolog by the preferential removal of polar compounds from moving compaction waters by retention on particularly adsorptive mineral surfaces, such as zeolitic claystones. It is uncertain, however, whether this speculative interpretation applies to the high toluene concentrations as observed in certain sediments of tuffaceous lithology in the present study.

\section{ACKNOWLEDGMENTS}

We gratefully acknowledge the financial support of the Deutsche Forschungsgemeinschaft, Schwerpunktprogramm "Ocean Drilling Program/Deep Sea Drilling Project" (grant no. We 346/27), and of Bundesanstalt für Geowissenschaften und Rohstoffe, Hannover, the German member organization of the Joint Oceanographic Institutions for Deep Earth Sampling (JOIDES), for providing the travel funds of one of the authors (R. L.) 
who participated in the ODP Leg 121 cruise. Thanks are also due to the U.S. National Science Foundation for supplying the samples for this study.

Organic carbon values were kindly provided by Dr. B. Horsfield (KFA Jülich). Technical assistance by Mrs. E. Biermanns, Mr. R. Harms, and Mr. H.-G. Sittardt is gratefully appreciated.

\section{REFERENCES}

Faber, E., Gerling, P., and Dumke, I., 1988. Gaseous hydrocarbons of unknown origin found while drilling. In Mattavelli, L., and Novelli, L. (Eds.), Advances in Organic Geochemistry 1987: Oxford (Pergamon Press), 875-879.

Hunt, J. M., 1974. Hydrocarbon and kerogen studies. In von der Borch, C. C., Sclater, J. G., et al., Init. Repts. DSDP, 22: Washington (U.S. Govt. Printing Office), 673-676.

1975. Origin of gasoline range alkanes in the deep sea. Nature, 254:411-413.

1984. Generation and migration of light hydrocarbons. Science, 226:1265-1270.

Jasper, J. P., Whelan, J. K., and Hunt, J. M., 1984. Migration of $C_{1}$ to $C_{8}$ volatile organic compounds in sediments from the Deep Sea Drilling Project, Leg 75, Hole 530A. In Hay, W. W., Sibuet, J.-C., et al., Init. Repts. DSDP, 75 (Pt. 2): Washington (U.S. Govt. Printing Office), 1001-1008.

Peirce, J., Weissel, J., et al., 1989. Proc. ODP, Init. Repts., 121: College Station, TX (Ocean Drilling Program).

Schaefer, R. G., and Leythaeuser, D., 1984. $C_{2}-C_{8}$ Hydrocarbons in sediments from Deep Sea Drilling Project Leg 75, Holes 530A, Angola Basin, and 532, Walvis Ridge. In Hay, W. W., Sibuet, J.-C., et al., Init. Repts. DSDP, 75 (Pt. 2): Washington (U.S. Govt. Printing Office), $1055-1067$.

1985. Low-molecular-weight hydrocarbons in sediments of Deep Sea Drilling Project Leg 89, Sites 585, East Mariana Basin, and 586, Ontong-Java Plateau. In Moberly, R., Schlanger, S. O., et al., Init. Repts. DSDP, 89: Washington (U.S. Govt. Printing Office), 577-586.

1987. Low-molecular-weight hydrocarbons in sediments of Deep Sea Drilling Project Leg 93, Hole 603B, off the east coast of
North America. In van Hinte, J. E., Wise, S. W., Jr., et al., Init. Repts. DSDP, 93: Washington (U.S. Govt. Printing Office), 1237-1244.

Schaefer, R. G., Leythaeuser, D., and Gormly, J., 1984. Generation and migration of low-molecular-weight hydrocarbons in sediments of Deep Sea Drilling Project Leg 79, Sites 544, 545, and 547, offshore Morocco. In Hinz, K., Winterer, E. L., et al., Init. Repts. DSDP, 79: Washington (U.S. Govt. Printing Office), 743-773.

Schaefer, R. G., Leythaeuser, D., and von der Dick, H., 1983a. Generation and migration of low-molecular-weight hydrocarbons in sediments from Site 511 of DSDP/IPOD Leg 71, Falkland Plateau, South Atlantic. In Bjorøy, M., et al. (Eds.), Advances in Organic Geochemistry 1981: Chichester (Wiley), 164-174.

Schaefer, R. G., von der Dick, H., and Leythaeuser, D., 1983b. $C_{2}-C_{8}$ hydrocarbons in sediments from Deep Sea Drilling Project Leg 71, Site 511, Falkland Plateau, South Atlantic. In Ludwig, W. J., Krasheninnikov, V. A., et al., Init. Repts. DSDP, 71: Washington (U.S. Govt. Printing Office), 1033-1043.

Schaefer, R. G., Weiner, B., and Leythaeuser, D., 1978. Determination of sub-nanogram per gram quantities of light hydrocarbons $\left(\mathrm{C}_{2}-\mathrm{C}_{9}\right)$ in rock samples by hydrogen stripping in the flow system of a capillary gas chromatograph. Anal. Chem., 50:1848-1854.

Whelan, J. K., 1984. Volatile $\mathrm{C}_{1}-\mathrm{C}_{8}$ compounds in marine sediments. In Odham, G., Larsson, L., and Mårdh, P.-A. (Eds.), Gas Chromatography/Mass Spectrometry. Applications in Microbiology Ser., New York (Plenum), 381-414.

Whelan, J. K., and Hunt, J. M., 1981. C $1-C_{8}$ Hydrocarbons in IPOD Leg 63 sediments from outer California and Baja California borderlands. In Yeats, R. S., Haq, B. U., et al., Init. Repts. DSDP, 63: Washington (U.S. Govt. Printing Office), 775-784.

1982. $C_{1}-C_{8}$ Hydrocarbons in Leg 64 sediments, Gulf of California. In Curray, J. R., Moore, D. G., et al., Init. Repts. DSDP, 64 (Pt. 2): Washington (U.S. Govt. Printing Office), 763-780.

Whelan, J. K., Hunt, J. M., Jasper, J., and Huc, A., 1984. Migration of $\mathrm{C}_{1}-\mathrm{C}_{8}$ hydrocarbons in marine sediments. In Schenck, P. A., de Leeuw, J. W., and Lijmbach, G.W.M. (Eds.), Advances in Organic Geochemistry 1983: Oxford (Pergamon Press), 683-694.

Date of initial receipt: 19 March 1990

Date of acceptance: 13 November 1990

Ms 121B-176 